\title{
Mathematizing Darwin
}

\author{
A. W. F. Edwards
}

Received: 17 July 2010 /Revised: 17 November 2010 /Accepted: 17 November 2010 /Published online: 5 January 2011

(C) The Author(s) 2010. This article is published with open access at Springerlink.com

\begin{abstract}
Ernst Mayr called the first part of the evolutionary synthesis the 'Fisherian synthesis' on account of the dominant role played by R.A. Fisher in forging a mathematical theory of natural selection together with J.B. S. Haldane and Sewall Wright in the decade 1922-1932. It is here argued that Fisher's contribution relied on a close reading of Darwin's work to a much greater extent than did the contributions of Haldane and Wright, that it was synthetic in contrast to their analytic approach and that it was greatly influenced by his friendship with the Darwin family, particularly with Charles's son Leonard.
\end{abstract}

Keywords Darwin · Fisher · Haldane · Wright · Evolution · Mathematical theory of natural selection

\section{Introduction}

The celebration of the sesquicentenary of the publication of The Origin of Species and the bicentenary of Darwin's birth is a good moment to look at the initial mathematical development of Darwin's theory of evolution by natural selection, especially at a meeting on Mathematical Models in Ecology and Evolution. About ecology I shall say nothing, and I shall also make a distinction between the study of evolution and that of mathematical models in Mendelian genetics. The two are closely related, of course,

Communicated by Guest Editor A. Houston

This contribution is part of the Special Issue 'Mathematical Models in Ecology and Evolution: Darwin 200' (see Marshall et al. 2010).

A. W. F. Edwards $(\bowtie)$

Gonville and Caius College, University of Cambridge,

Cambridge, UK

e-mail: awfe@cam.ac.uk but whereas mathematical genetics is an analytic approach, mathematical evolution is synthetic, attempting to draw out general principles rather than pursuing the reductionist approach that Ernst Mayr so memorably called 'beanbag genetics'.

No better example of the synthetic approach can be found than Düsing's mathematical treatment of Darwin's argument for natural selection favouring an equality of the sexes, forgotten until I drew attention to it in an article in The American Naturalist in 1998. This famous argument, though it used to be attributed to R.A. Fisher in The Genetical Theory of Natural Selection published in 1930, we now know was given by Darwin in the first edition of The Descent of Man and Selection in Relation to Sex of 1871 but omitted from the second edition of 1874. In that edition, Darwin remarked 'but I now see that the whole problem is so intricate that it is safer to leave its solution to the future', as Fisher noted.

In 1883 and 1884, Carl Düsing of Jena took Darwin's argument from the first edition and expounded it mathematically. I published an English translation of the relevant pages of Düsing's 1884 book in 2000. You will of course already have observed that in 1883 Mendel's paper had not yet received the attention it had from 1900 onwards, so that Düsing's treatment is pre-Mendelian, synthetic. There is no genetical model, merely the Darwinian assumption that there exists heritable variation in the tendency to produce one sex in excess.

In the initial years of the twentieth century following the rediscovery of Mendel's paper, two major reconciliations had to take place. The first was the synthesis of the findings of Karl Pearson's biometrical school and the Mendelian model of inheritance. Initiated by Udny Yule in 1902, this culminated in Fisher's first major publication The correlation between relatives on the supposition of Mendelian 
inheritance of 1918. The details of this famous paper, the foundation of biometrical genetics, do not now concern us because evolution is not its topic. The second reconciliation was, of course, the synthesis of Darwinian evolution by natural selection and Mendelian genetics. This proved to be more drawn out because, as Peter Bowler in his 1983 book The Eclipse of Darwinism and Jean Gayon in Darwinism's Struggle for Survival (English edition 1998) have chronicled, in the early years of the century the followers of the Mendelian school of William Bateson, and many others, were strongly opposed to the suggestion that evolution could proceed by the accumulation of the small changes that Mendelism seemed to offer and Darwinism require.

I shall try to persuade you that once again the youthful Fisher was the principal contributor, and that his 1930 book The Genetical Theory of Natural Selection (and some papers that preceded it) was the major event of the first part of what Julian Huxley was to call 'the evolutionary synthesis', that complete reconciliation of Darwin's theory not only with Mendelian genetics but also with the natural world described by Huxley, Dobzhansky, Mayr, Simpson and other natural historians. Mayr went so far as to call this first part 'the Fisherian synthesis'. The important decade is 1922-1932, and I have described it in detail in a 2001 encyclopaedia article 'Darwin and Mendel united: The contributions of Fisher, Haldane and Wright up to 1932'. I shall argue that Haldane and Wright were not only later than Fisher, but that their work was primarily analytic, starting from simple Mendelian models and deducing the consequences, whereas Fisher achieved a synthesis based to a great extent on his reading of Darwin. He made the distinction himself in his paper at the Sixth International Congress of Genetics in 1932, when he contrasted his approach with Haldane's:

The one approach [Haldane's] ... is analytic and deductive. Genetic studies are regarded as revealing the mechanism connecting cause and effect, from a knowledge of which the workings of the machine can be deduced and the course of evolutionary change inferred. The other approach is inductive and statistical; genetics supplies the facts as to living things as they now are, facts which ... have an evolutionary history and may be capable of an evolutionary explanation .... .

In using the word 'statistical', Fisher is here referring to the great strides that he and others were making at the time in the inductive subject of statistical inference through the introduction of maximum likelihood and significance testing. The title of Fisher's paper was 'The evolutionary modification of genetic phenomena', and in this and in an address to the Royal Society of Dublin earlier in 1932 'The bearing of genetics on theories of evolution', one can see how far Fisher was already concerned not just with deducing the evolutionary consequences of genetic systems but, like Darwin, with the subtler problem of drawing inductive conclusions about the evolution of those systems themselves from the mass of biological observations often requiring statistical interpretation. With good reason Richard Dawkins remarked in The Blind Watchmaker that Fisher was the greatest of Darwin's successors.

\section{Fisher the Darwinist}

(I call a 'Darwinist' anyone who closely studies and develops Darwin's own arguments, in contrast to a 'Darwinian', who simply subscribes to Darwin's theory of evolution by natural selection.)

Fisher came up to Gonville and Caius College in the University of Cambridge to read mathematics in October 1909, shortly after the University had celebrated Darwin's first centenary. He has left us with some reminiscences: 'I first came to Cambridge in 1909, the year in which the centenary of Darwin's birth and the jubilee of the publication of The Origin of Species were being celebrated. The new school of geneticists using Mendel's laws of inheritance was full of activity and confidence, and the shops were full of books good and bad from which one could see how completely many writers of this movement believed that Darwin's position had been discredited'. 'The fiftieth anniversary of the publication of The Origin of Species was being celebrated, apart from other things, by the publication of Bateson's book Mendel's Principles of Inheritance' (actually Mendel's Principles of Heredity). Fisher bought the book: 'It includes a translation of Mendel's paper on "Pisum". Caius and the Cambridge Department of Genetics are mounting a small exhibition to commemorate Fisher's admission to the college a hundred years ago.

In his last year at Harrow School, Fisher had chosen the collected works of Darwin for a school prize, so that, in the words of his biographer Joan Box, 'he went up to Cambridge in possession of volumes he was to read and reread with loving care throughout his life'. These 13 volumes of the John Murray edition, bound in green cloth, are preserved in Adelaide, where Fisher died in 1962. In Cambridge, he received as a College Prize the book of essays Darwin and Modern Science published by Cambridge University Press as part of the Darwin Celebrations ('a remarkable collection of able essays', Fisher was later to remark) and as a gift from his undergraduate friend C.S. Stock, The Foundations of the Origin of Species: Two Essays Written in 1842 and 1844 by C. Darwin. 
So great was the impact of The Origin of Species on Fisher and Stock that a few years later, in 1915, they were to write in response to one of Darwin's critics:

So melancholy a neglect of Darwin's work suggests reflections upon the use of those rare and precious possessions of man - great books. It was, we believe, the custom of the late Professor Freeman to warn his students that mastery of one great book was worth any amount of knowledge of many lesser ones. The tendency of modern scientific teaching is to neglect the great books, to lay far too much stress upon relatively unimportant modern work and to present masses of detail of doubtful truth and questionable weight in such a way as to obscure principles. ... How many biological students of today have read The Origin? The majority know it only from extracts, a singularly ineffective means, for a work of genius does not easily lend itself to the scissors; its unity is too marked. Nothing can really take the place of a first-hand study of the work itself.

(Professor E.A. Freeman was Regius Professor of Modern History at Oxford, 1884-1892.)

Fisher was from the outset influenced by Darwin's writings to a much greater extent than any of his contemporaries; he was a successor in the truest sense. In 1948, he received the Darwin Medal of the Royal Society and in replying to D.J. Finney's congratulations had this to say:

Of course it was an immense satisfaction to me to have the Darwin Medal awarded, as I have worked for a good many years, and indeed saw the need nearly 40 years ago, to reverse the trend then prevalent of misrepresenting and minimizing the importance of Darwin's achievement. The books and articles to be bought in Cambridge in 1909, the year in which the centenary of Darwin's birth was celebrated, make very strange reading today, and it is relevant to anyone really interested in the way science makes progress that the writers of the first 10 years of the century, which began with the rediscovery of Mendel's work, were so biased against Darwin and natural selection by the controversies preceding this rediscovery that much that Mendel himself said in his 1865 paper was completely overlooked.

Fisher's 1915 paper with Stock, from which I have already quoted, is a vigorous defence of Darwin against criticism of his theory of evolution by L. Cuénot, and in the same year Fisher published his first evolutionary paper, 'The evolution of sexual preference', with the opening sentence: 'Of the branches of biological science to which Charles Darwin's life-work has given us the key, few, if any, are as attractive as the subject of Sexual Selection'. As Peter O'Donald remarked, 'Fisher took the theory a fundamental step further than Darwin by showing how mate choice itself would evolve as a consequence of the very process of sexual selection it produced'. Fifteen years later, Fisher devoted a section of The Genetical Theory of Natural Selection to this topic.

A further reason for Fisher's emergence as the bestinformed Darwinist of his generation was that his knowledge of Darwin's writings was reinforced by the friendship of two of Darwin's sons, Horace and Leonard, and the acquaintance of two more, Francis and George. In 1911, Fisher and some fellow-undergraduates canvassed support for the formation of a Cambridge University Eugenics Society, and succeeded in forming a Council which included Dampier Whetham, R.C. Punnett, John Maynard Keynes (not a bad choice as Treasurer), A.C. Seward and Horace Darwin, Charles's youngest son, as well as Fisher himself. In February 1912, Major Leonard Darwin, Charles's fourth surviving son, who had become President of the national Eugenics Education Society in 1911, came to address the Cambridge Society. As Joan Box tells us 'The link was strengthened that summer when the First International Eugenics Congress took place in London under Major Darwin's presidency, when Fisher, with other Cambridge members, served as stewards at the meetings'. Two more Darwin brothers, Francis and George, were also involved in the Cambridge Society. Francis was to give the first Galton Lecture of the Eugenics Education Society in 1914 and George the Lecture in 1939. In 1930, Charles Galton Darwin, George's son, was to review The Genetical Theory for the Eugenics Review.

Leonard Darwin in particular soon became a major influence on Fisher. From 1915 onwards, the two men conducted an extensive correspondence, much of it reproduced by J.H. Bennett in his 1983 book Natural Selection, Heredity and Eugenics, which also gives the fullest account of their interaction. It suffices to say here that Leonard was at once a friend, a father-figure, a supporter and a wise adviser, always ready to discuss his father's views. Fisher dedicated The Genetical Theory of Natural Selection

TO
MAJOR LEONARD DARWIN
In gratitude for the encouragement,
given to the author, during the last
fifteen years, by discussing many
of the problems dealt with
in this book

We may also note in passing that Fisher's 1918 paper 'The correlation between relatives on the supposition of Mendelian inheritance' ends with the words 'Finally, it is a pleasure to acknowledge my indebtedness to Major 
LEONARD DARWIN, at whose suggestion this inquiry was first undertaken, and to whose kindness and advice it owes its completion'. Indeed, Darwin saw to its publication following its withdrawal from the Royal Society after unfavourable reports by Karl Pearson and R.C. Punnett ('both of whom I later succeeded', Fisher used to say).

\section{The Genetical Theory of Natural Selection}

Whilst many of Fisher's papers refer explicitly to Charles Darwin (see the name index in Volume 5 of his Collected Papers), it is mainly to The Genetical Theory that we must turn to substantiate the view that he was the leading mathematizer of Darwin's theory. It would be facile simply to repeat the opinions of distinguished scientists about this book, but many may be found in three dedicated publications, the Introduction in Bennett's book, his Foreword to the Variorum Edition of The Genetical Theory and my own 'Perspectives' article devoted to the book in Genetics in April 2000.

A word must be said about Fisher's style before embarking on a discussion of the Darwinian content of The Genetical Theory. Fisher was a consummate mathematician trained in the hard school of the Cambridge Mathematical Tripos, as those of you who have studied his statistical work will know, but when writing for a more general audience he often suppressed the mathematical basis of his arguments in an attempt (usually unsuccessful) to make them more accessible, especially to biologists. Indeed, many of us have had to struggle to construct (or reconstruct) the mathematics, as for example Walter Bodmer and I did in 1960 with Fisher's discussion of natural selection and the sex ratio (thus covering the same ground as Düsing of course, unknown to us or anyone else at the time), and O'Donald has done with sexual selection and the evolution of dominance.

In his Foreword to the variorum edition, Bennett devotes 11 pages to an account of The Genetical Theory. Attention should also be drawn to the Summaries with which Fisher ended each chapter. Here, I shall only discuss the topics that have a clear connection to Darwin's writings. That connection could hardly be stronger than in Chapter I where Fisher contrasts the tendency of a blending theory of inheritance to reduce the variance of a character in a population (described by some simple mathematics) with the conservation of the variance implicit in Mendelian inheritance, a comparison he had first made in 1924. Throughout the chapter, Fisher shows great familiarity not only with Darwin's books but also with his correspondence and with his essays of 1842 and 1844. Michael Bulmer has given an extended account of the problem in his book Francis Galton: Pioneer of Heredity and Biometry, pointing out that Darwin's theory of pangenesis actually only involved partial blending 'since the patent elements fuse but the latent elements do not'.

In Chapter II of The Genetical Theory, in a section entitled 'The genetic element in variance', Fisher introduces his 'fundamental theorem of natural selection' showing that the instantaneous increase in the mean fitness of a population ascribable to natural selection acting through changes in gene frequencies is exactly equal to its additive genetic, or genic, variance at that time. Much has been written about the fundamental theorem, a lot of it misleading, and this is not the moment to review how a full understanding of Fisher's meaning has been arrived at.

Rather, it is important to see this theorem as part of the central Darwinian theme that variation is the meat and drink of evolution by natural selection. The first chapter of The Origin of Species is entitled 'Variation under Domestication' and is preliminary to Chapter II 'Variation under Nature'. Following Darwin's lead, in 1922 Fisher had set out to investigate how the variance of a population is maintained or increased, and how it decays. After showing (for the first time) that heterozygote advantage leads to balanced polymorphism, he studied the survival of individual mutant genes by introducing the Galton-Watson branching process and analysing it by functional iteration. $\mathrm{He}$ then set up the chain-binomial model for a simple population (often now incorrectly called the Wright-Fisher model), treating it by a diffusion approximation (thereby inventing stochastic diffusion theory in the process) and deriving partial differential equations for the study of genefrequency distributions in populations of finite size. As we shall see, these topics are developed in Chapters IV and V of The Genetical Theory. For the moment I just want you to note the date, 1922, and the Darwinian context. Indeed Fisher quotes what he calls 'the dictum of Charles Darwin', that 'wide ranging, much diffused and common species vary most' from Chapter II of The Origin.

Chapter III of The Genetical Theory is devoted to the evolution of dominance, a matter which had been engaging Fisher's attention in several papers at the time of writing the book, involving exchanges with both Haldane and Wright. Bennett writes 'This work contributed in an important way to the growth of the concept of the gene-complex' but it is, of course, essentially post-Darwin in its subject matter. It is an example of how Fisher's thinking was already directed at the evolution of genetic systems, as I mentioned earlier.

Chapters IV and V essentially constitute one long chapter entitled "Variation as determined by mutation and selection'. The Summary itself covers more than three pages. This is the heart of the book, and the most mathematical. The 1922 results are corrected and extended as Fisher studies the effects of mutation rate, population size and selection on the variance, and on the survival of individual 
genes, concluding, as is well known, that natural selection operating in large populations is likely to be of much greater evolutionary significance than chance variation in small ones. His analysis leads him to conclude, in accordance with Darwin's dictum, that the more numerous species will tend to be the more variable, and will make the most rapid evolutionary progress, supplanting less abundant groups, as Darwin foresaw. Fisher's stance in the longrunning controversy with Wright and his 'shifting-balance' theory of evolution has a very definite Darwinian origin. Looking again at stable polymorphism, this time Fisher proves convergence to and not just the stability of the equilibrium in the case of heterozygote advantage. He also discusses the population genetics of two linked loci, once again putting into English what might have been easier to follow in mathematics, as others (such as Haldane) have since done.

Chapter VI 'Sexual reproduction and sexual selection' is more Darwinian than even Fisher realized, for it contains the section 'Natural selection and the sex-ratio' which, as we have seen, he did not trace to its origin in the first edition of The Descent of Man. In 'Fission of species' he describes sympatric speciation - 'the case of a species subject to different conditions of survival and reproduction at opposite ends of its geographical range'-and shows how 'The constant elimination in each extreme region of the genes which diffuse from it to the other, must involve incidentally the elimination of those types of individuals which are most apt to diffuse' leading to an increasing contrast in the genetic composition of the two parts and their ultimate independence. This is a typically Fisherian addition to a Darwinian theory, the theory of divergence in Chapter IV of The Origin. By adding the notion that the aptitude to diffuse is also heritable, Fisher has supplied a powerful dynamic.

Here I might mention that many years ago, in 1962, I wrote a short paper called 'Migrational selection' which I had (quite properly) forgotten. Now that I recall it, I find that I had been reading the section 'Fission of species', which is heavily marked up in my original paperback copy of The Genetical Theory. In a footnote I mention 'Fisher (1950) has since [1930] given a mathematical formulation of this problem', and this is a rare example of him mathematizing a Genetical Theory discussion. But his paper is also memorable for quite a different reason. The differential equation Fisher obtains required numerical solution, so he appealed to his friend Maurice Wilkes, the constructor of the first Cambridge EDSAC computer, who asked a student, David Wheeler, to tabulate it. I believe this to be the first use of a computer to tackle a problem in biology, and I have been stating this for so long without a challenge that it may even be true. A personal reason for now remembering my paper is that I asked the editor of
Heredity, Kenneth Mather, if I could dedicate it to Fisher, who had just died. He said no.

The long section on 'Sexual selection' in Chapter VI derives directly from The Descent of Man and, as we have already seen, adds substantially to the theory by introducing the 'runaway' process Fisher first described in 1915. This is another example where Fisher has suppressed the mathematics, for Bennett has written 'Fisher never published anything on the quantitative basis for his runaway process although he had, in fact, set this out in correspondence with C.G. Darwin in 1932'. O'Donald's 1980 book Genetic Models of Sexual Selection gives a detailed historical account as well as many mathematical models. Last in Fisher's chapter comes the section 'Natural selection and the sex-ratio' already mentioned.

In Chapter VII 'Mimicry', Fisher remarks that the theory of mimicry is 'the greatest post-Darwinian application of Natural Selection'. The chapter is notable particularly for the section 'The evolution of distastefulness' [in insects] which he explains by what is now known as 'kin selection', often attributed to Haldane but in fact suggested by Fisher already in a student talk in 1912 published in 1914 when he considered how a childless man killed in war could be replaced genetically speaking by his nephews.

The last five chapters, on Man, which Fisher regarded as 'strictly inseparable' from the rest of the book, are more Galtonian than Darwinian, but they do reflect the influence of Leonard Darwin, whose The Need for Eugenic Reform had appeared in 1926. Dedicated to the memory of his father, in the preface Leonard thanks Fisher for statistical advice and proof-reading. In Chapter VIII of The Genetical Theory, 'Man and Society', Fisher discusses the evolution of fertility, recalling how Leonard Darwin, taking the parasitic cuckoo as his example, had in his book introduced the concept of parental expenditure on the young in this connection (also used by Fisher when discussing natural selection and the sex-ratio in Chapter VI). David Lack much later wrote an influential paper 'The evolution of reproductive rates' in ignorance of Fisher's discussion. Reviewing the problem in 1992, David Burbridge observed that Leonard Darwin had thought his own contribution original, but in fact 'his father had discussed the problem in the first edition of The Descent of Man and given essentially the same solution'. But he removed it from the second edition and 'As later biologists seldom consulted the scarce first edition, Darwin's contribution seems to have been forgotten even by his own son'. This is exactly what had happened with natural selection and the sex-ratio, so once again we find that a Fisherian discussion actually derives from Charles Darwin without Fisher realizing it. But in this case Darwin was himself following an insight of Herbert Spencer's.

In my 'Perspectives' article I remarked, in connection with Fisher's literary style, that 'it is illuminating to think of 
The Genetical Theory as a kind of mathematical-Mendelian appendix to The Origin of Species'; I should have added 'and The Descent of Man (first edition)'. My article should be consulted for further information about The Genetical Theory, such as its writing and its reception. In addition, let us not forget that whilst writing it Fisher was the fulltime Head of the Statistics Department at Rothamsted Experimental Station and had, in 1925, published his book Statistical Methods for Research Workers, which was to become so renowned that it was the only statistical writing to be granted a chapter in the volume Landmark Writings in Western Mathematics 1640-1940 edited by Ivor Grattan-Guinness.

\section{Sewall Wright and J.B.S. Haldane}

Fisher's description of Haldane's approach as 'analytic and deductive' can also be applied to Wright's. To a much greater extent than Fisher they both established genetical models and pursued their consequences, Haldane from 1924 in a series of papers and Wright from 1931 starting with his influential paper 'Evolution in Mendelian populations', the final version of a manuscript that he had been polishing since 1925. I have discussed their contributions at length in my 'Darwin and Mendel united' article of 2001, where summary biographical details will also be found. But my present purpose is to study the mathematization of Darwin and therefore to enquire only into the extent of Darwin's influence on Wright and Haldane.

Wright was certainly well-read in Darwin, whose Origin of Species he had studied as a student as well as other books about Darwinism, but what the historian of science W.B. Provine called his 'two most seminal early papers on evolutionary theory' contain no references to Darwin's writings. These two papers in 1931 and 1932 set the scene for much of Wright's extensive subsequent publications on evolution, but he hardly ever mentioned Darwin.

It is interesting to note that Wright first learnt of Mendelian heredity through the 1911 article by Punnett in the 11th edition of the Encyclopedia Britannica which he had been set to read by Mrs Key, his teacher at Lombard College, Galesburg, Illinois. Punnett was a young Fellow of Caius College in 1909 when Fisher was admitted, and the author of the little book Mendelism (1905, second edition 1907). Provine also mentions that later in graduate school Wright read Lock's (1906) Recent Progress in the Study of Variation, Heredity and Evolution, which was known in the United States through being used as a text book by E.B. Wilson at Columbia University. R.H. Lock, an associate of William Bateson, was also a young Fellow of Caius until 1910 , though he left for Ceylon in 1908. Wilson had been one of the recipients of an Honorary Doctorate at the
Cambridge Darwin Celebrations and would probably have met Lock then. Thus, Wright initially shared Fisher's intellectual background to some extent, but without such a strong emphasis on Darwin. Provine writes 'Until reading Fisher's 1922 paper [in 1924], it had not occurred to Wright to extend his own quantitative analysis to the statistical distribution of genes in populations'.

Haldane's intellectual background has been described by his biographer Ronald Clark and is not noted for any special influence of Darwin's writings. His own The Causes of Evolution of 1932 arose from a series of lectures he gave at the University of Wales, Aberystwyth, in 1931, entitled 'A Re-examination of Darwinism'. They show a wide knowledge of Darwinism and its development but, as is entirely understandable in lectures to a general audience, do not suggest any deep study of Darwin's work. Indeed, rather amusingly, in five pages of bibliography the only Darwin reference is 'Darwin and Wallace (1858), Journ. Linn. Soc. July 1' which he mentioned in the first sentence of the book! In a long Appendix 'Outline of the mathematical theory on natural selection' Haldane summarized much of his own work in the series of papers starting in 1924.

Wright and Haldane were indeed Darwinians, but they were not Darwinists in the sense in which I have used the word, and, with their analytic model-building approach, cannot be considered to have been 'mathematizing Darwin' to the extent that Fisher was. Mayr's description 'the Fisherian synthesis' is understandable.

\section{The second part of the evolutionary synthesis}

Long before he coined the phrase 'Fisherian synthesis', Mayr (1980) divided the evolutionary synthesis into two 'conclusions':

The term "evolutionary synthesis" was introduced by Julian Huxley in Evolution: The Modern Synthesis (1942) to designate the general acceptance of two conclusions: gradual evolution can be explained in terms of small genetic changes ("mutations") and recombination, and the ordering of this genetic variation by natural selection; and the observed evolutionary phenomena, particularly macroevolutionary processes and speciation, can be explained in a manner that is consistent with the known genetic mechanisms.

Julian Huxley, grandson of T.H. Huxley, 'Darwin's bulldog', is now remembered more as a writer about the evolutionary synthesis than as a contributor to it, especially through Evolution: The Modern Synthesis. In the first chapter Huxley did of course summarize Darwin's achievement (and coin the phrase 'The eclipse of Darwinism', later 
to be used by Bowler as a book title), but in the preface he acknowledges his primary influences: 'I owe a great debt to J.B.S. Haldane's The Causes of Evolution' and 'My debt to R.A. Fisher's work is obvious'. Interestingly, he attended the Cambridge Darwin celebrations in 1909: 'As a Huxley and a budding biologist, I was invited, and was deeply impressed by the stream of addresses stressing the importance of Darwin's many-sided work'. He added:

I resolved that all my scientific studies would be undertaken in a Darwinian spirit and that my major work would be concerned with evolution, in nature and man. This was not so much a turning point in my career as a crystallization of my ideas, a clear vision and inspiration which I can truly say remained with me all through my life.

Huxley was a true Darwinian, subscribing to and promoting Darwin's theory and its subsequent development, but not a Darwinist.

In Mayr's second 'conclusion' of the evolutionary synthesis, that 'the observed evolutionary phenomena ... can be explained in a manner that is consistent with the known genetic mechanisms', the three most influential contributions were the books by Theodosius Dobzhansky, G.G. Simpson and Mayr himself. All emerged from Columbia University Press under the editorship of L.C. Dunn; the first two paid homage to Darwin in their titles: Genetics and the Origin of Species (Dobzhansky 1937) and Systematics and the Origin of Species (Mayr 1942). Simpson's (1944) could also have done so as 'Paleontology and the Origin of Species' but was in fact called Tempo and Mode in Evolution.

Neither Dobzhansky nor Simpson gave any of Darwin's works in their copious bibliographies. Mayr gave just The Origin of Species and offered a number of incidental comments on Darwin's contributions. All three were one stage removed from Darwin and were able to rely on the supposition that the work of Fisher, Haldane and Wright had achieved the synthesis of Mendelism and Darwinian evolution by natural selection. Indeed, for the most part they did not follow this work closely, mainly because of its substantial mathematical content. Dobzhansky relied heavily on Wright's work but the details defeated him. In his long opening address to the 1955 Cold Spring Harbor Symposium on Quantitative Biology 'A review of some fundamental concepts and problems of population genetics' he ventured to describe what happens at a diallelic locus with heterozygotic advantage. He says that the significant fact is that the mean fitness reaches a maximum at equilibrium. Thus 'Selection maximises the adaptive value of the population, even at the expense of making the latter contain some handicapped individuals [the homozygotes]. The fitness of some individuals is sacrificed for the fitness of the population as a whole'. I don't think we would let an undergraduate get away with that.
Mayr himself became a historian of the evolutionary synthesis, and together with Provine edited the results of a 1974 conference held to discuss it (The Evolutionary Synthesis, Mayr and Provine 1980), a starting point for any student of the topic today. He became fascinated by Darwin even if his early work had not been particularly influenced by him. In the Preface to his One Long Argument-Charles Darwin and the Genesis of Modern Evolutionary Thought, Mayr wrote 'My interest in Darwin's thought arose in my university years, but my more active preoccupation began in 1959 with the centenary of the publication of On the Origin of Species. I studied Darwin's writings even more intensely when I prepared an introduction to a facsimile of the first edition of the Origin, published in 1964'.

In my 2000 'Perspectives' article on The Genetical Theory, I criticized Mayr since he 'never seems to have come to terms with [The Genetical Theory's] importance'. 'In The Evolutionary Synthesis (Mayr 1980) he contributed a "Prologue: Some thoughts on the history of the evolutionary synthesis" without once mentioning The Genetical Theory (unless a remark about "the supposedly evolutionary writings of ... R.A. Fisher" counts as a mention)'. Mayr and I had been corresponding intermittently for years, starting in 1964 or earlier, and in 2001 we were discussing Fisher's view of sympatric speciation in the course of which I sent him a copy of my 'Perspectives' article and drew attention to the criticisms of him it contained. This led to much further friendly correspondence in which Mayr objected to Fisher's 'gene-centred' view of evolution (which I maintained was a misunderstanding on Mayr's part) but most interestingly he wrote 'Actually I don't think I read Fisher before I came to Harvard in 1953, and even then perhaps not right away'. The correspondence continued through 2003.

\section{Conclusion}

Fisher's reputation as having an oversimplified 'genecentred' view of evolution is often promoted by those who, like Mayr, have not studied The Genetical Theory properly and have fallen into the trap of assuming that he was ploughing the same furrow as Haldane and Wright. Indeed, it is customary to follow Lancelot Hogben's 1931 initiative and mention Fisher, Haldane and Wright in the same breath. But as we have seen, Fisher was a Darwinist, and, like his hero, adopted a synthetic approach to evolution in contrast to Haldane and Wright, whose approaches were much more analytic, exploring the evolutionary consequences of the genetical models they set up. Ironically for one who established the fundamental model of balanced polymorphism in 1922, Fisher rarely constructed specific models. Indeed when, in 1959, O'Donald asked him why he had written so little on [mathematical genetics] after 1930, he 
replied that it had seemed to him that the mathematics had already by then gone beyond the available data'.

Failure to distinguish the synthetic and analytic approaches is the main reason why for so many years the fundamental theorem of natural selection was itself misunderstood, to the detriment of both Fisher's reputation and the advance of understanding. Mathematicians (mainly) viewed it analytically and became excited when they discovered population-genetic models in which the mean fitness was not an increasing function. The rest of us were more cautious and finally came to see that it was central to Fisher's mathematizing of Darwin. Wright's analytical version, in which he attempted to saddle a population's mean fitness with the properties of a potential function, was one of the principle butts of Fisher's invective.

The myth that Fisher's whole approach was analytic and 'single-locus' dies hard. As recently as last year, even the respected author of The Eclipse of Darwinism, Bowler, could write:

'... we arrive at what Ronald Aylmer Fisher called in the title of his 1930 book The Genetical Theory of Natural Selection. Fisher's theory ignored the possibility that genes might interact with one another and worked with a simple model in which each gene coded for a particular variant form of a character. ... it was then a straightforward procedure to assign a degree of "fitness" to each gene ... .'

Countering such widespread misapprehension requires the same dedication to reading Fisher, especially The Genetical Theory, as Fisher applied to reading Darwin, especially The Origin of Species and The Descent of Man.

I shall leave you with some advice of Fisher's. Exactly 50 years after he came up to Cambridge, there was another Darwin anniversary to celebrate, this time the centenary of the publication of The Origin. Fisher had this to say:

A centenary celebration is an occasion for retrospect, yet I submit, though the view is an old-fashioned one, that the purpose of retrospect is to prepare ourselves for the future, by avoiding the unnecessary repetition of the errors of the past.

More attention to the History of Science is needed, as much by scientists as by historians, and especially by biologists, and this should mean a deliberate attempt to understand the thoughts of the great masters of the past, to see in what circumstances or intellectual milieu their ideas were formed, where they took the wrong turning or stopped short on the right track.

I hope I have demonstrated to you that the intellectual milieu in which Fisher's contributions were formed was the writings of Darwin, and that this placed him in a unique position to lead the synthesis of Darwinism with Mendelism. A century after the immersion of Fisher in Darwinian Cambridge, we can see even more clearly why Dawkins called him the greatest of Darwin's successors.

Acknowledgements My understanding of all matters relating to Darwin and Fisher has, for more than 50 years, benefitted from conversations with Dr Peter O'Donald, Fellow of Emmanuel College, to whom I am most grateful. In particular, he emphasized Fisher's distinction between the inductive and deductive approaches to the study of evolution in the introductory chapter to his 1980 book Genetic Models of Sexual Selection, which I had the pleasure of reading in draft.

Only on recently re-reading Alan Grafen's 2003 lecture 'Fisher the evolutionary biologist', which I had heard him deliver, did I discover that he described Fisher as 'Darwin's mathematician', thus no doubt sowing the seed of the title of this lecture in my subconscious mind.

Open Access This article is distributed under the terms of the Creative Commons Attribution Noncommercial License which permits any noncommercial use, distribution, and reproduction in any medium, provided the original author(s) and source are credited.

\section{Bibliography}

Bateson W (1909) Mendel's principles of heredity. Cambridge University Press, Cambridge

Bennett JH (ed) (1983) Natural selection, heredity, and eugenics. Clarendon, Oxford

Bodmer WF, Edwards AWF (1960) Natural selection and the sex ratio. Ann Hum Genet 24:239-244

Bowler PJ (1983) The eclipse of Darwinism. Johns Hopkins University Press, Baltimore

Bowler PJ (2008) Survival of the "fittest". Regal 1:116-138

Box JF (1978) R.A. Fisher: the life of a scientist. Wiley, New York

Bulmer M (2003) Francis Galton: pioneer of heredity and biometry. Johns Hopkins University Press, Baltimore

Burbridge D (1992) Lacking a solution? Nature 355:118

Clark R (1968) J.B.S.: the life and work of J.B.S. Haldane. Hodder and Stoughton, London

Crew FAE (1969) Recollections of the early days of the Genetical Society. In: Jinks J (ed) Fifty years of genetics. Oliver \& Boyd, Edinburgh

Crow JF (1990a) R.A. Fisher, a centennial view. Genetics 124:207-211

Crow JF (1990b) Fisher's contributions to genetics and evolution. Theor Popul Biol 38:263-275

Darwin C (1859) On the origin of species by means of natural selection. Murray, London (facsimile reprint with an introduction by E. Mayr, Harvard University Press, 1964)

Darwin C (1871) The descent of man, and selection in relation to sex. Murray, London (2nd edn., 1874, Murray, London)

Darwin C (1909) The foundations of the origin of species, two essays written in 1842 and 1844 by C. Darwin. In: Darwin F (ed). Cambridge University Press, Cambridge

Darwin CG (1930) Natural selection. Eugen Rev 22:127-130

Darwin L (1926) The need for eugenic reform. Murray, London

Dawkins R (1986) The blind watchmaker. Longman, London

Dobzhansky T (1937) Genetics and the origin of species. Columbia University Press, New York

Dobzhansky T (1955) A review of some fundamental concepts and problems of population genetics. Cold Spring Harbor Symp Quant Biol 20:1-15 
Edwards AWF (1963) Migrational selection. Heredity 18:101-106

Edwards AWF (1990) R.A. Fisher: twice professor of genetics: London and Cambridge or "A fairly well-known geneticist". Biometrics 46:897-904

Edwards AWF (1992) Likelihood (expanded edition). Johns Hopkins University Press, Baltimore

Edwards AWF (1993) Mendel, Galton, Fisher. Aust J Stat 35:129-140

Edwards AWF (1994) The fundamental theorem of natural selection. Biol Rev 69:443-474

Edwards AWF (1995) Fiducial inference and the fundamental theorem of natural selection. Biometrics 51:799-809

Edwards AWF (1998) Natural selection and the sex ratio: Fisher's sources. Am Nat 151:564-569

Edwards AWF (2000a) Carl Düsing (1884) on the regulation of the sex ratio. Theor Popul Biol 58:255-257

Edwards AWF (2000) The genetical theory of natural selection. In: Crow JF, Dove WF (ed) Perspectives. Genetics 154:1419-1426

Edwards AWF (2001) Darwin and Mendel united: the contributions of Fisher, Haldane and Wright up to 1932. In: Reeve ECR (ed) Encyclopedia of genetics. Fitzroy Dearborn, London, pp 77-83

Edwards AWF (2005) R.A. Fisher, statistical methods for research workers, First Edition (1925). In: Grattan-Guinness I (ed) Landmark writings in Western mathematics, 1640-1940. Elsevier, Amsterdam, pp 856-870

Fisher RA (1914) Some hopes of a eugenist. Eugen Rev 5:309-315

Fisher RA (1915) The evolution of sexual preference. Eugen Rev 7:184-192

Fisher RA (1918) The correlation between relatives on the supposition of Mendelian inheritance. Trans R Soc Edinb 52:399-433

Fisher RA (1922) On the dominance ratio. Proc R Soc Edinb 42:321-341

Fisher RA (1924) The biometrical study of heredity. Eugen Rev 16:189-210

Fisher RA (1925) Statistical methods for research workers. Oliver \& Boyd, Edinburgh

Fisher RA (1930a) The distribution of gene ratios for rare mutations. Proc Roy Soc Edinb 50:205-220

Fisher RA (1930) The genetical theory of natural selection. Clarendon Press, Oxford (2nd edn., 1958, New York, Dover. Variorum edition, Bennett JH (ed), 1999, Oxford University Press)

Fisher RA (1932a) The bearing of genetics on theories of evolution. Sci Prog 27:273-287

Fisher RA (1932b) The evolutionary modification of genetic phenomena. Proc 6th Int Congr Genetics 1:165-172

Fisher RA (1947) The renaissance of Darwinism. Listener 37:1001

Fisher RA (1950a) Gene frequencies in a cline determined by selection and diffusion. Biometrics 6:353-361

Fisher RA (1950b) Contributions to mathematical statistics. Wiley, New York

Fisher RA (1952) Statistical methods in genetics. Heredity 6:1-12

Fisher RA (1954) Retrospect of criticisms of the theory of natural selection. In: Huxley J, Hardy AC, Ford EB (eds) Evolution as a process, 84-98. Allen \& Unwin, London

Fisher RA (1959) Natural selection from the genetical standpoint. Austr J Sci 22:16-17

Fisher RA (1971-74) Collected papers of R.A. Fisher, volumes I-V. In: Bennett JH (ed). University of Adelaide, Australia

Fisher RA, Stock CS (1915) Cuénot on preadaptation. A criticism. Eugen Rev 7:46-61

Gayon J (1998) Darwinism's struggle for survival. Cambridge University Press, Cambridge

Grafen A (2003) Fisher the evolutionary biologist. The Statistician $52: 319-329$

Haldane JBS (1931) A mathematical theory of natural selection. Pt. VIII. Metastable populations. Proc Camb Phil Soc 27:137-142

Haldane JBS (1932) The causes of evolution. Longman Green, London
Hamilton WD (1964) The genetical evolution of social behaviour, II. J Theor Biol 7:17-51

Hogben L (1931) Genetic principles in medicine and social science. Williams and Norgate, London

Hunt BJ (1991) The Maxwellians. Cornell University Press, New York

Huxley JS (1936) Natural selection and evolutionary progress. British Association Annual Meeting Report, 81-100

Huxley JS (1942) Evolution, the modern synthesis. Allen \& Unwin, London

Huxley JS (1954) The evolutionary process. In: Huxley J, Hardy AC, Ford EB (eds) Evolution as a process. Allen \& Unwin, London, pp $1-23$

Huxley JS (1970) Memories I. Allen \& Unwin, London

Jones S, Keynes M (eds) (2007) Twelve Galton lectures. Galton Institute, London

Kendall DG (1990) Obituary, Andrei Nikolaevich Kolmogorov (1903-1987). Bull Lond Math Soc 22:31-100

Kimura M (1964) Diffusion models in population genetics. Methuen's monographs on applied probability and statistics. Supplementary Review Series in Applied Probability 2

Lack D (1954) The evolution of reproductive rates. In: Huxley J, Hardy AC, Ford EB (eds) Evolution as a process, 143-156. Allen \& Unwin, London

Lock RH (1906) Recent progress in the study of variation, heredity and evolution. Murray, London

Marshall J, McNamara J, Houston A (2010). The state of Darwinian theory. Behav Ecol Sociobiol. doi:10.1007/s00265-010-1121-y

Mayr E (1942) Systematics and the origin of species. Columbia University Press, New York (reprinted 1999 with a new Introduction, Harvard University Press, Cambridge)

Mayr E (1982) The growth of biological thought. Belknap, Cambridge

Mayr E (1980) Prologue, some thoughts on the history of the evolutionary synthesis. In: Mayr E, Provine WB (eds) The evolutionary synthesis, 1-48. Harvard University Press, Cambridge

Mayr E (1991) One long argument: Charles Darwin and the genesis of modern evolutionary thought. Harvard University Press, Cambridge

Mayr E (1999) see 1942

Mazumdar PMH (1992) Eugenics, human genetics and human failings. Routledge, London

O'Donald P (1986) Models for the evolution of dominance. Proc R Soc B 171:127-143

O’Donald P (1980) Genetic models of sexual selection. Cambridge University Press, Cambridge

O'Donald P (1990) Fisher's contributions to the theory of sexual selection as the basis of recent research. Theor Popul Biol $38: 285-300$

Provine WB (1978) The role of mathematical population geneticists in the evolutionary synthesis of the 1930s and 1940s. Stud Hist Biol 2:167-192

Provine WB (1986) Sewall Wright and evolutionary biology. University of Chicago Press, Chicago

Provine WB (1990) Discussion: population genetics. Bull Math Biol 52:201-207

Punnett RC (1905) Mendelism. Bowes and Bowes, Cambridge

Punnett RC (1911) Mendelism. In: The Encyclopædia Britannica, 11th edn., 18:115-120. New York

Regal B (ed) (2008) Icons of evolution. Greenwood, Westport

Seward AC (ed) (1909) Darwin and modern science. Cambridge University Press, Cambridge

Simpson GG (1944) Tempo and mode in evolution. Columbia University Press, New York

Shaw RF, Mohler JD (1953) The selective significance of the sex ratio. Am Nat 87:337-342

Wilkins A (2008) Neo-Darwinism. Regal 2:491-515 
Williams GC (1996) Adaptation and natural selection. Princeton University Press, Princeton

Wright S (1930) The genetical theory of natural selection, a review. J Hered 21:340-356

Wright S (1931) Evolution in Mendelian populations. Genetics 16:97-159

Wright S (1932) The roles of mutation, inbreeding, crossbreeding and selection in evolution. Proc Sixth Int Congr Genet 1:356-366
Wright S (1968-78). Evolution and the genetics of populations (I Genetic and biometric foundations; II The theory of gene frequencies; III Experimental results and evolutionary deductions; IV Variability within and among natural populations). University of Chicago Press, Chicago

Yule GU (1902) Mendel's laws and their probable relations to intraracial heredity. New Phytol 1(193-207):222-238 